\title{
Morphology of Gonads, Maturity and Spawning Season of Loricariichthys spixii (Siluriformes, Loricariidae) in a Subtropical Reservoir
}

\author{
Silvana Duarte ${ }^{1}$, Francisco Gerson Araújo ${ }^{1 *}$, Armando Sales $^{2}$ and Nilo Bazzoli ${ }^{3}$ \\ ${ }^{1}$ Laboratório de Ecologia de Peixes; Universidade Federal Rural do Rio de Janeiro; Km 47; Antiga Rodovia Rio - \\ SP; 23851-970; gerson@ufrrj.br; Seropédica - RJ - Brasil. ${ }^{2}$ Laboratório de Histologia e Embriologia; \\ Universidade Federal Rural do Rio de Janeiro; Km 47; Antiga Rodovia Rio - SP; 23851-970; Seropédica - RJ - \\ Brasil. ${ }^{3}$ Departamento de Morfologia; Instituto de Ciências Biológicas; Universidade Federal de Minas Gerais; \\ C.P. 486; 30161-970; Belo Horizonte - MG - Brasil
}

\begin{abstract}
The gonad morphology and spawning season of Loricariichthys spixii in Lajes reservoir were described based on 175 males and 613 females. Cells from the spermatogenic lineage were divided in four phases: spermatogonia (primary and secondary), spermatocytes (primary and secondary), spermatids and spermatozoa, and the cells from the ovocitarian lineage were divided in four phases: primary oocytes (O1), previtellogenic oocytes (O2), cortical vesicle oocytes (O3) and yolk globules or vitellogenic (O4). Five gonadal stages were described for the males/females according to oocytes and spermatogenic lineage cells distribution: resting (1); initial maturation (2a); advanced maturation (2b); partially spent/spawned (4a); totally spent/spawned (4b). Spawning was iteroparous, occurring throughout the year. Resting/recover occurred in July/August for the females coinciding with lower temperature and rainfall and decreasing water level. The wide spawning period was the part of the strategy developed to withstand environmental pressure and to get success in this oligotrophic and poorly structured environment.
\end{abstract}

Key words: Loricariidae, reservoir, fish reproduction, gonad morphology, Brazil

\section{INTRODUCTION}

The armored catfish Loricariichthys spixii is one of the most abundant members of the Loricariidae family in the freshwater environment of Southeastern Brazil. It has successfully adapted to manmade lakes formed from impounded rivers, where fish composition has shift in response to changes in hydrological system (Duarte and Araújo, 2001). Few studies on its reproduction at Lajes reservoir, the largest man-made lake in Rio de Janeiro State, are available. Spawning season, as indicated by the gonadosomatic index occur mainly from August to November, and the resting from April to June. The gonadal cycle also has been estimated based on macroscopic observation and five stages have been described (Araújo et al., 1998; Duarte and Araújo, 2000).

Studies on the reproductive biology that incorporate histological examination of gonads usually are suitable to determine the precise duration of the spawning period and whether spawning occurs more than once in a breeding season. Many freshwater fish species in the

\footnotetext{
${ }^{*}$ Author for correspondence
} 
subtropical or tropical waters have long spawning seasons, whereas those species that inhabit temperate waters, where conditions in winter are more severe, typically have shorter and more clearly defined breeding periods (Conover, 1992). The emphasis here has been placed on describing the temporal trends exhibited by reproductive variables, such as the gonadosomatic index, maturation stages, based on gonadal development of the germinative cells. Bazzoli (1992) studied aspects of morphology and histochemical of the oogenes of 10 species of Loricariidae, among them, one species of Loricariichthys. To date, information on detailed aspects of gonad morphology of $L$. spixii in a manmade environment in Southeastern Brazil are lacking. The present work assessed the reproductive biology of $L$. spixii based on the description of the gonadal development and determination of the spawning season on Lajes reservoir; also eventual influences of environmental variables on the reproductive cycle were evaluated.

\section{MATERIALS AND METHODS}

\section{Study area}

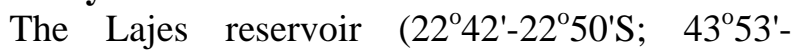
$44^{\circ} 05^{\prime} \mathrm{W}$ ) is the largest dammed water collection in Rio de Janeiro State, Brazil (Fig. 1). The dam was built in the beginning of the last century for hydroelectric purposes, and is one of the oldest impounded environments in Brazil. The surface area is approximately $30 \mathrm{~km}^{2}$, at ca. $415 \mathrm{~m}$ above sea level. The water has excellent quality, with no significant influences of human activities (Barroso, 1989).

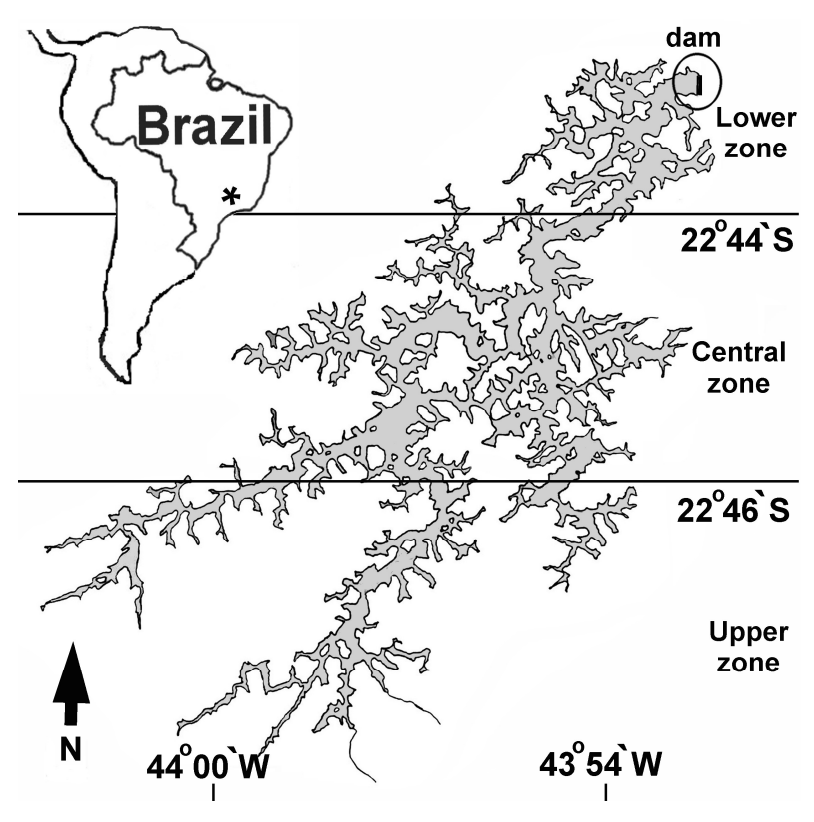

Figure 1 - Study area, Lajes reservoir, Rio de Janeiro, Brazil

\section{Sampling}

A total of 170 males and 613 females were collected by bimonthly sampling programme, from January 1996 to December 1997. Fishes were collected with $2.5-4.5 \mathrm{~cm}$ (stretched mesh) gillnets. Individuals were selected ranging from 28 to 42 $\mathrm{cm}$ only to calculate parameters of the reproductive cycle. Identification followed the original description of Steindachner (1881).

\section{Biometry and gonadosomatic index}

Measurements of total length (TL, $\mathrm{cm}$ ), total weight $(\mathrm{W}, \mathrm{g})$, gonad weight $(\mathrm{GW}, \mathrm{g})$ and cellomic cavity length $(\mathrm{cm})$ were taken for each specimen by the sex and by the stage of the gonadal maturity. Gonadosomatic index (GSI $=\mathrm{GW} /(\mathrm{W}$ GW) x 100) was calculated. 


\section{Light microscopy}

Slices were taken from the posterior portion of the gonads. Fragments were fixed in Bouin during 4-8 $\mathrm{h}$ and submitted to ordinary histological techniques. Preserved ovaries were embedded in the paraffin, sectioned at 5-7 $\mathrm{mm}$ thickness and stained with Harris haematoxylin and eosin (HE).

\section{Stages of cycle reproductive}

Stages of reproductive cycle were determined for the males and females based on both the macro and microscopic characteristics of the gonads and on the gametogenic cell distribution. Testes were classified according to form and size of the cysts, which were patches of germinative cells in different spermatogenesis stages (Bazzoli and Godinho, 1991; Santos et al. 2001), while oocytes were classified according to the changes in the nucleus, cytoplasm and in the peripherics follicles: zona pellucida, follicles cells and theca. (Bazzoli and Rizzo, 1990). Stages of the reproductive cycle were classified according to Bazzoli (1992). Spawning type was defined according to the stage of the reproductive cycle frequencies and histological analyses for spent ovarian

\section{Environmental variables}

Water temperature, transparency and $\mathrm{pH}$ were taken by a digital multisensor Horiba mod. U-10, at each sampling occasion. Level of water of the reservoir and the rainfall were supplied by LIGHT (Meteorological Station), the power station concessionaire of the reservoir.

\section{Statistical analyses}

Two-way analysis of variance (ANOVA) was used to compare environmental variables and GSI means among years and months. When there were significant differences, a ‘a posteriori SNK test was used to identify which values were significantly different at a=0.05 level (Zar, 1984).

Raw data were previously $\log 10 \quad(\mathrm{x}+1)$ transformed to address the normality and homocedasticity assumptions of ANOVA. The Chi-square test was used to compare sex rate for each class interval of total length and for the whole examined sample. Linear regression procedures were used to assess the slope and the y-intercept for the relationship between gonad weight (dependent variable) and total weight (independent variable) for each maturation stage.

\section{RESULTS}

\section{Morphology of the gonads}

Macroscopic examination confirmed that gonads were paired, longitudinally flattened, located in dorso-posterior region, attached to coellomic wall cover by the mesorc and mesovarium. Testes were filliform and ovaries fairly cylindrical. The gonads joined each other at the caudal region, forming a common duct, opening at the uro-genital papillae. Males were observed in all the stages of the reproductive cycle. Testes were with transversal folds in the median region. The anterior border was streamlined or slightly curved in the early maturation stages and truncated in the others stages of the reproductive cycle (Fig. 2).

The testes and ovaries were covered by the albuginea tunic of conjunctive origin, by hundreds of smooth muscular cells and blood vessels. They emitted septs to the inner part of the organ, forming lobes that were filled by the seminiferous tubules in the testis (Fig. 3), and in ovarian lamellae in which oocytes in different development phases were found in the ovaries (Fig. 4).

In the testis, the seminiferous tubules were formed by cysts, defined by the cytoplasmatic projections of Sertoli cells. In each cyst, the spermatogenetic lineage cells were found in the similar development phase of the ovarian lineage cell, changing according to reproductive cycle stage. The main morphological characteristics of the testis and ovaries in the different stages of the reproductive cycle are shown in Table 1.

\section{Spermatogenesis}

\section{Spermatogonia}

These were of two types - primary and secondary. Primary spermatogonia were the largest cells of the spermatogenic lineage, presenting clear cytoplasm, large and prominent nucleus. They occurred isolated and presented no cysts. The secondary spermatogonia were formeded from the primary ones, showing smaller size and formed cysts of 2 to 4 cells. 


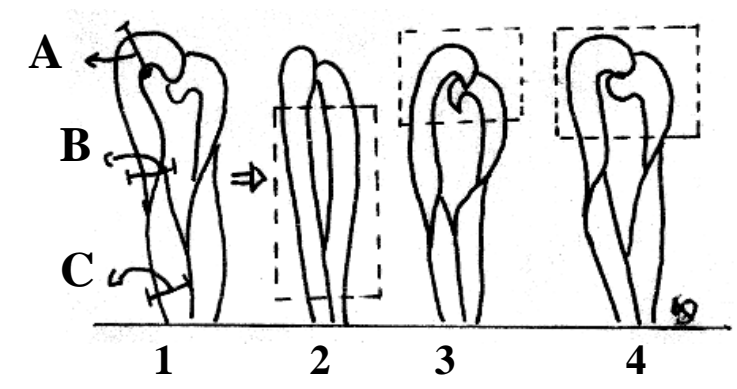

Figure 2 - Schematic drawing showing macroscopic morphology of the testis (1) of Loricariichthys spixii: cranial (A), median (B) and caudal (C) regions for adults. Anatomic aspects during the reproductive cycle: retile (2), curvilinear (3) and truncated (4) indicate the immature (2) and mature (3 and 4) condition

\section{Spermatocytes}

They were divided in the primary and secondary spermatocytes. The primary spermatocytes were formed after repeated mitotic divisions of the secondary spermatogonia. They were shown in several phases of the meiotic prophase, commonly zygoten and pachyten. The nucleus was prominent with filamentous chromatin. The secondary spermatocytes were smaller than the primary ones and presented the nucleus with slightly condensed chromatin in one of the poles.

\section{Spermatids}

They originated from the secondary spermatocytes being smaller than those. Cytoplasm scarce. Nucleus was spherical and dense. These cells suffered modifications until they became spermatozoa.

\section{Spermatozoa}

They were the smallest cells of the spermatogenic lineage. The nucleus was round and very dense. They were concentrated in the lumen of the tubules after breaking the cyst wall.

\section{Oogenesis}

\section{Primary oocyte (O1)}

Oocytes diameter was small; vitreous cytoplasm, basophilic, large nucleus, prominent, centralized and with peripheric nucleolus.

\section{Previtellogenic oocyte (O2)}

Cytoplasm was finely granulated, with nucleolus attached to nuclear wrapping. The vitellinic nucleus was shown in the cytoplasm, as a conspicuous structure, basophilic, located close to the nucleus. The zona pellucida was thin and the follicle cells are pavimentous.

\section{Oocytes with cortical vesicles $(\mathbf{O 3})$}

It was characterized by the presence of the vesicles in the whitish cytoplasm. Nucleus was central, badly delineated and the nucleolus were randomly distributed. Cytoplasm lost gradually the basophilic characteristics. The pellucida zone was thin and the follicles cells were cubic.

\section{Vitellogenic oocytes (O4)}

Yolk globules in the cytoplasm could be seen. The pellucida zone remained thin and the follicles cells became prismatic.

The composition and distribution of the cells of spermatogenic and ovarian lineage changed according to the stages of the reproductive cycle. The main morphologic characteristics of the testes and ovaries and stages of the reproductive cycle are shown in Table 1. 
Table 1 - Comparison of macroscopic and histological appearance of males and females for Loricariichthys spixii in the Lajes reservoir, RJ, 1996-1997.

\begin{tabular}{|c|c|c|}
\hline $\begin{array}{c}\text { Maturity } \\
\text { Stage }\end{array}$ & Testis & Ovary \\
\hline 1 & No fish caught in this stage. & $\begin{array}{l}\text { Whitish-yellow color. Ovary takes up } 40 \% \text { of } \\
\text { coelomic cavity; weight averaging } 7.4 \mathrm{~g} . \\
\text { Presence of } \mathrm{O} 1 \text { and } \mathrm{O} 2 \text { oocytes. }\end{array}$ \\
\hline $2 \mathrm{a}$ & $\begin{array}{l}\text { Aspect filliform and whitish color. The } \\
\text { testis are thin, taking up } 38 \% \text { of cellomic } \\
\text { cavity. Weight up to } 0.2 \mathrm{~g} \\
\text { The testis presents few spermatozoas } \\
\text { and large number of other spermatogenic } \\
\text { lineage cells (Fig.3.1) }\end{array}$ & $\begin{array}{l}\text { Yellowish, turgid, with oocytes visible to naked } \\
\text { eyes. Blood vessels no evident. The ovary occupies in } \\
\text { average } 72 \% \text { of coellomic cavity and weights around } \\
11.6 \mathrm{~g} \\
\quad \text { Presence of } \mathrm{O} 1 \text { and } \mathrm{O} 2 \text {; few } \mathrm{O} 3 \text { oocytes }\end{array}$ \\
\hline $2 b$ & $\begin{array}{l}\text { Aspect of ribbon. White color. Turgid } \\
\text { and voluminous. The testis taking up to } 81.6 \\
\% \text { of coelomic cavity and weights up to } \\
0.5 \mathrm{~g} \text {. } \\
\text { Predominance of spermatozoas in } \\
\text { relation to the other spermatogenic lineage } \\
\text { cells (Fig. 3.2) }\end{array}$ & $\begin{array}{l}\text { Strong yellow coloration, voluminous, very turgid } \\
\text { and with many vitellogenic oocytes, visible to naked } \\
\text { eye. Blood vessels evident. Ovary taking in mean } 86.7 \% \\
\text { of coelomic cavity and weights approximately } 22.5 \mathrm{~g} \\
\text { (Fig. } 4.1 \text { ) } \\
\text { Presence of O1, O2 and O3. Large numbers of O4. }\end{array}$ \\
\hline $4 \mathrm{a}$ & $\begin{array}{l}\text { Testis white to reddish and with flaccid } \\
\text { parts. It takes in average } 76.7 \% \text { of coellomic } \\
\text { cavity, and weights until } 0.4 \mathrm{~g} \text {. } \\
\text { Numerous spermatozoa when compared } \\
\text { to the other spermatogenic lineage cells. } \\
\text { Lumen partially empty (Fig.3.3). }\end{array}$ & $\begin{array}{l}\text { Reddish, flaccid, with vitellogenic oocytes. Ovary } \\
\text { occupies in average } 78.0 \% \text { of the coellomic cavity, } \\
\text { weights c.a. } 19.0 \mathrm{~g} \\
\text { Presence of } \mathrm{O} 1, \mathrm{O} 2, \mathrm{O} 3, \mathrm{O} 4 \text {, and post-ovullatory } \\
\text { follicles and atresy. }\end{array}$ \\
\hline $4 \mathrm{~b}$ & $\begin{array}{l}\text { Testis reddish, very hemorrhagic and } \\
\text { flaccid, taking up to } 75.0 \% \text { of coellomic } \\
\text { cavity, with weight averaging } 0.4 \mathrm{~g} \text {. } \\
\text { Only spermatozoa are found and the } \\
\text { lumen of seminiferous tubules is open. }\end{array}$ & $\begin{array}{l}\text { Ovary dark-red and hemorrhagic, flaccid, with } \\
\text { numerous opaque oocytes (atresic), visible to naked eye. } \\
\text { Ovary occupying in mean } 68.8 \% \text { of coellomic cavity, } \\
\text { weighting approximately } 14.1 \mathrm{~g} \text { (Figs. } 4.2 ; 4.3 \text { and } 4.4 \text { ) } \\
\text { Presence of O1, O2, and many post-ovullatory } \\
\text { follicles. Oocytes O3 and O4 when present, in atresic } \\
\text { stage. }\end{array}$ \\
\hline
\end{tabular}

1 = rest, $2 \mathrm{a}=$ initial maturation; $2 \mathrm{~b}=$ advanced maturation; $4 \mathrm{a}=$ partially spawn/spent; $4 \mathrm{~b}=$ totally spawn/spent

\section{Morphological characteristics of the stages of the reproductive cycle}

\section{Sex rate}

Significant differences were found according to Chi-square test $\left(\chi^{2}=328.9 ; \mathrm{P}<0.01\right)$, with the overall number of females $(78.7 \%)$ being higher than the number of males $(21.3 \%)$ (Table 2). Secondary sexual dimorphism was a well- evidenced character by the form and size of the labial papillae. Males presented an elongated and flatted papilla, while in females this papillae was of smaller size and relatively rougher. The more elongated papillae in males were associated with the broodcare, which occurred after fecundation, with males carrying the eggs in the antero-ventral part until eggs eclosion (Fig. 5). 


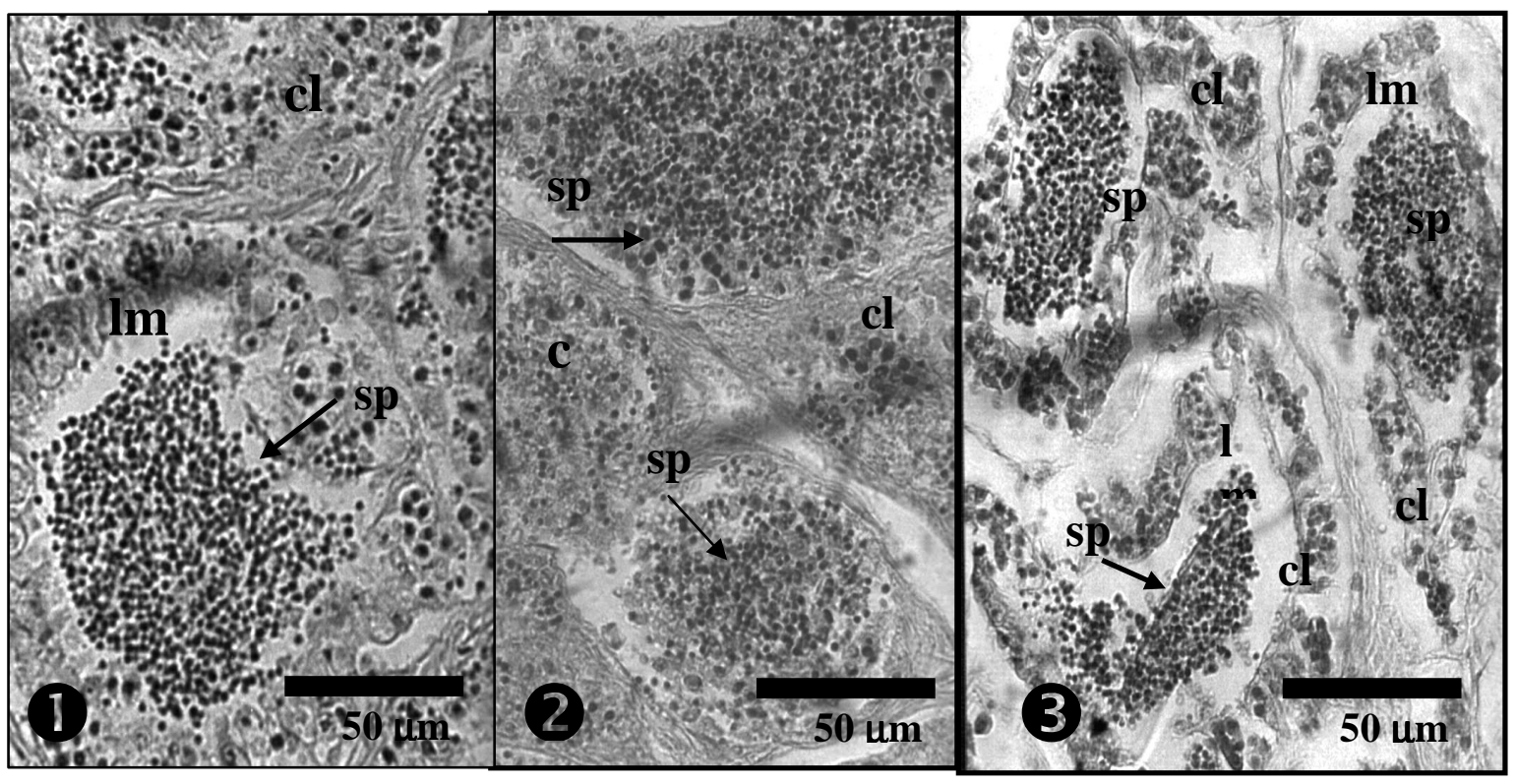

Figure 3 - Cross section of the testes of Loricariicthys spixii (1, 2, 3) showing different phases of development, stained by Hematoxilin-Eosin. 1 = Testis in initial maturation (stage 2a) with abundant spermatozoa (sp) in the lumen ( $\mathrm{lm}$ ) of the seminiferous tubes, large amount of spermatogenic lineage cells $(\mathrm{cl})-370 \mathrm{x} ; 2$ = Testis in advanced maturation (stage $2 \mathrm{~b}$ ) with abundant amount of spermatozoa (sp) in the lumen $(\mathrm{lm})$ in the seminiferous tubules, small amount of spermatogenic lineage cells $(\mathrm{cl})-370 \mathrm{x} ; 3=$ Testis partially spent (stage 4A) showing seminiferous tubules open with large amount of spermatozoa and other spermatogenic lineage cells $(\mathrm{cl})$ and lumen partially empty $(\mathrm{lm})-370 \mathrm{x}$

\section{Gonadosomatic index of males}

The gonadosomatic index for each maturation stage, as well as the values of the parameters (a) and (b) and of the linear relationship between the weight of the testis and the total fish weight are presented in Table 3.

\section{Gonadosomatic index of females}

The gonadosomatic index for each maturation stage, as well as the values of the parameters (a) and (b) of the linear relationship between the weight of the ovary and the total fish weight are presented in Table 4. Higher mean values for females were recorded in September/December 1996, March/April-1997, and September / October-1997. The lowest mean values were found consistently in July/August in 1996 and 1997 (Table 4; Fig. 6).

\section{Spawning season}

The GSI values differed significantly among sex according to ANOVA, being higher for the females and lower for the males, but no clear temporal (bimonthly or yearly) pattern of variation was shown during the studied period. Males showed higher GSI in September/October 1996, when compared with March/June-1996 and Nov1996 to June-1997 (Table 5).

\section{Environmental variables}

Significant differences were found for mean temperatures among bimonth and years, with significant interactions bimonthly $v s$. yearly (Table 6; Fig. 7). Peaks of temperature were recorded in January/February and the lowest records in July/August. Water transparency also presented significant differences between the years and bimonthly, and significant interaction between these two factors occurred. Highest values occurred in July/August and lowest values in November/December in 1996; no significant changes were recorded in 1997. 


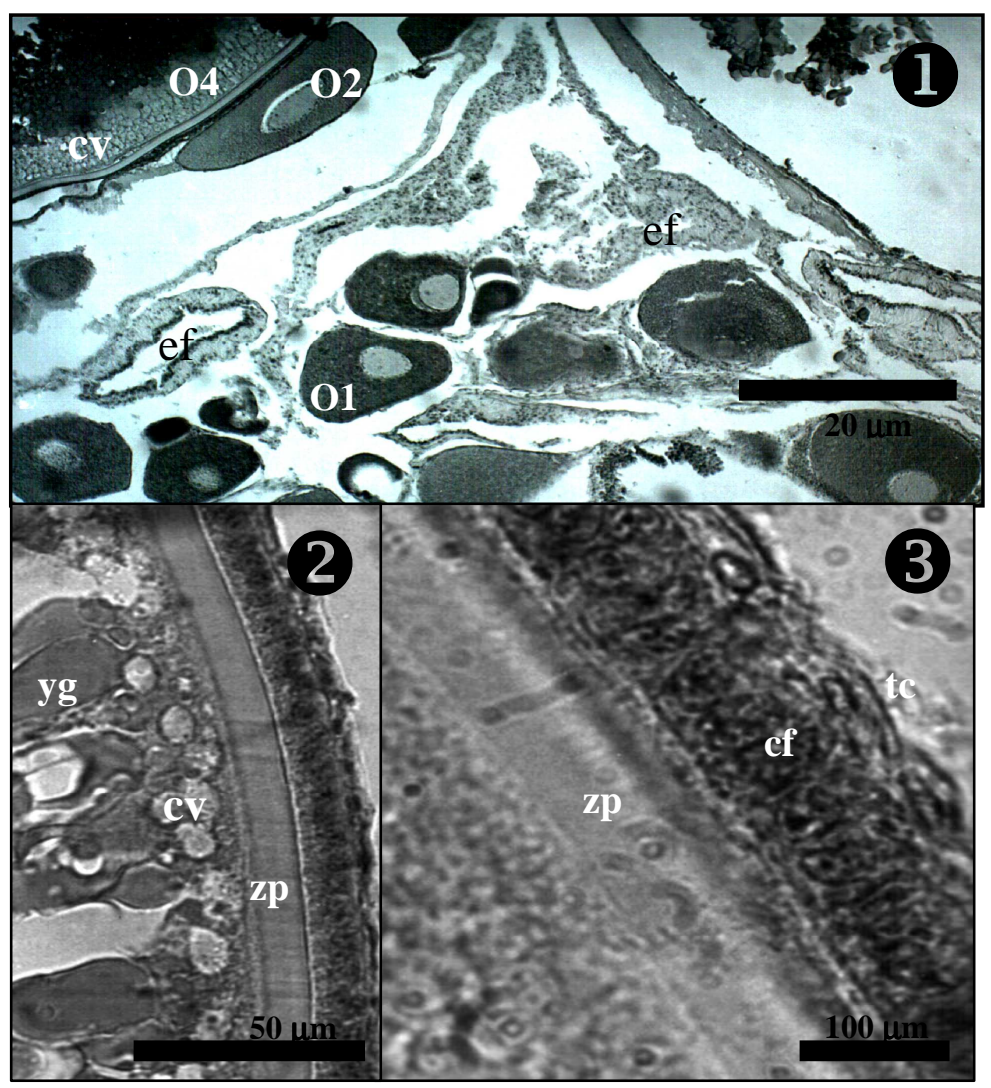

Figure 4 - Cross section of the ovarians of Loricariicthys spixii $(1,2,3)$ showing different phases of oocyte development, stained by Hematoxilin-Eosin. 1 = partial spawning (sub-stage 4 a) with young oocytes (O1) and previtellogenic oocytes (O2), vitellogenic oocytes (O4) e empty follicles (ef) $120 x ; 2=$ Section of vitellogenic oocyte (O4) with large cortical vesicles (cv), yolk globules (yg), follicles and thin zona pellucida (zp) 370x; 3 $=$ follicle membrane of yolk oocyte formed by zona pellucida (zp), follicles cells (fc) and teca (tc) $870 \mathrm{x}$

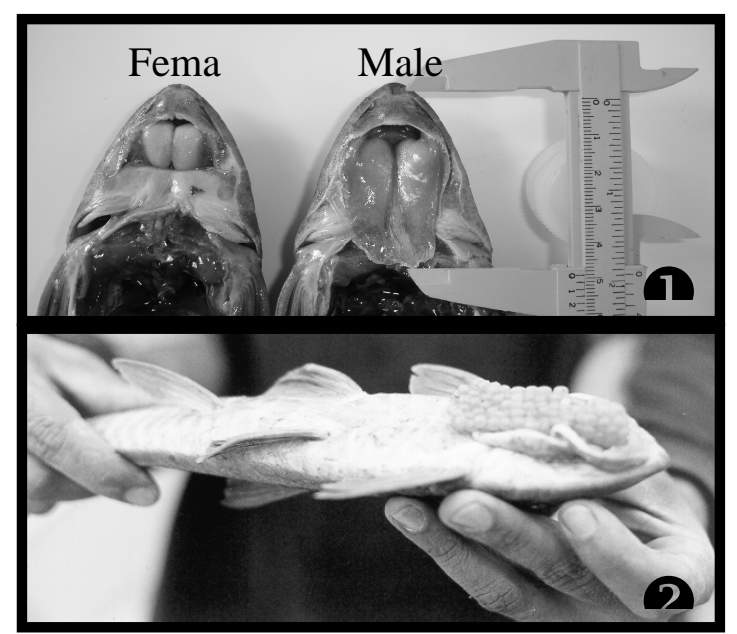

Figure 5 - Sexual secondary dimorphism in Loricariicthys spixii associated to parental care. Males showing larger elongated lips than females (1). Males carrying eggs in the lips (2) 


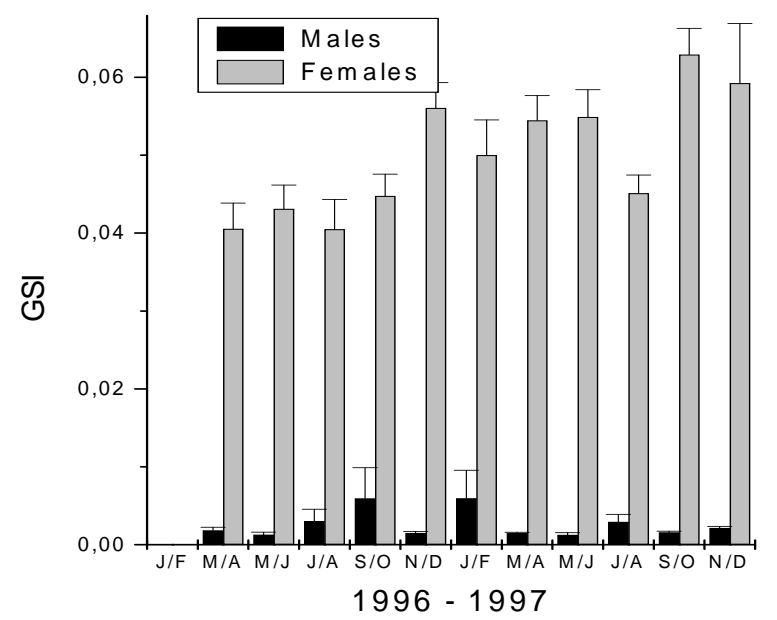

Figure 6 - Bi-monthly means and standard error (vertical lines) for gonadosomatic index for Loricariichthys spixii by sex in Lajes reservoir, RJ, 1996-1997

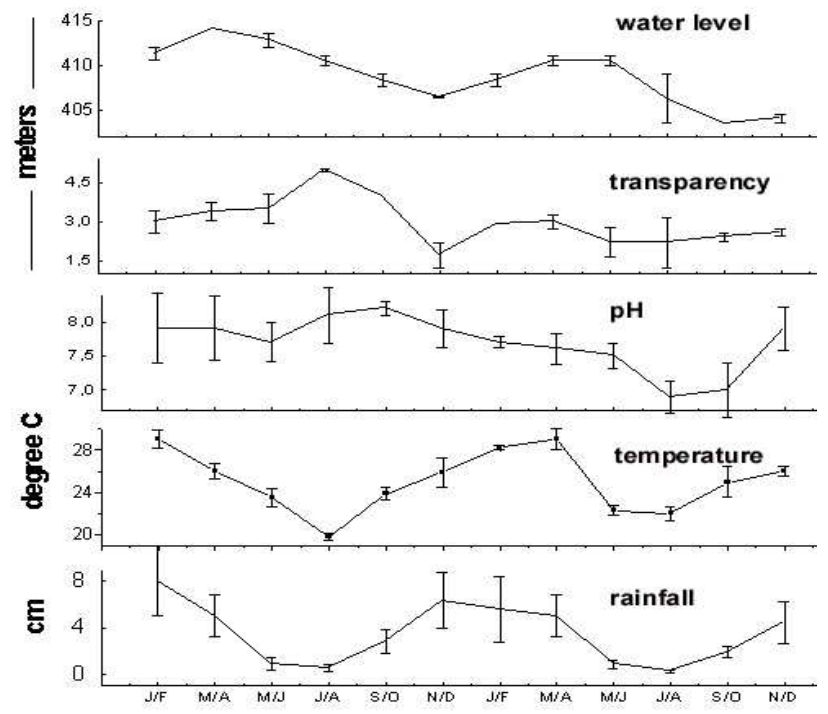

Figure 7- Bi-montly variation in environmental variables means and standard errors (vertical lines) for Lajes reservoir, 1996-1997 
Table 2 - Distribution of number (n), percentage (\%) e expected frequency (ef) from Chi-square test for comparison by size class of Loricariichthys spixii in Lajes reservoir, 1996-1997. ** $\mathrm{P}<0.01$.

\begin{tabular}{cccccccc}
\hline Size class & \multicolumn{2}{c}{ Males } & \multicolumn{2}{c}{ Females } & Total & Fe & $\boldsymbol{x}^{2}$ \\
\cline { 2 - 6 } TL $(\mathbf{m m})$ & $\mathbf{n}$ & $\mathbf{\%}$ & $\mathbf{n}$ & $\mathbf{\%}$ & $\mathbf{( n )}$ & & 0.0 \\
\hline $175-225$ & 1.0 & 50.0 & 1.0 & 50.0 & 2.0 & 1.0 & 0.3 \\
$225-275$ & 1.0 & 33.0 & 2.0 & 66.7 & 3.0 & 1.5 & 0.36 \\
$275-325$ & 37.0 & 53.6 & 32.0 & 46.37 & 69.0 & 34.5 & $64.0^{* *}$ \\
$325-375$ & 112.0 & 29.5 & 268.0 & 70.5 & 380.0 & 190.0 & $250.9^{* *}$ \\
$375-425$ & 15.0 & 4.9 & 294.0 & 95.1 & 308.0 & 154.0 & $9.3 * *$ \\
$425-475$ & 1.0 & 7.7 & 12.0 & 92.3 & 13.0 & 6.5 & $4.0^{* *}$ \\
$475-525$ & 0.0 & 0.0 & 4.0 & 100.0 & 4.0 & 2.0 & $\mathbf{3 2 8 . 8 6 * *}$ \\
\hline Total & $\mathbf{1 6 7 . 0}$ & $\mathbf{2 1 . 3}$ & $\mathbf{6 1 3 . 0}$ & $\mathbf{7 8 . 7}$ & $\mathbf{7 8 3 . 0}$ & $\mathbf{3 9 1 . 5}$ & $\mathbf{3 2 8 . 8}$ \\
\hline
\end{tabular}

Table 3 - Means and dispersion parameters for gonadosomatic index (GSI) for males of Loricariichthys spixii, in different maturation stages and parameters of the linear regression of testis weight on body weight.

\begin{tabular}{ccccccc}
\hline Stage & $\begin{array}{c}\text { GSI } \\
\text { Average }\end{array}$ & $\begin{array}{c}\text { Standard } \\
\text { deviation }\end{array}$ & Confidence Interval & $\mathbf{a}$ & b & n \\
\hline 1 & & & $0.146-0.0005$ & & & 52 \\
$2 \mathrm{a}$ & 2.48 & 3.57 & $0.0697-0.0097$ & 0.0036 & 0.00241 & 10 \\
$2 \mathrm{~b}$ & 8.51 & 6.46 & $0.0522-0.0005$ & 2.3359 & -0.0113 & 61 \\
$4 \mathrm{a}$ & 3.33 & 0.91 & $0.0071-0.0005$ & 0.1540 & 0.00167 & 47 \\
\hline $\mathrm{b}$ & 1.67 & 0.92 & -0.0549 & 0.00198 & \\
\hline
\end{tabular}

$\mathrm{n}=$ number of individuals; $\mathrm{a}=$ regression constant; $\mathrm{b}=$ regression coefficient.

Table 4 - Means and dispersion parameters for gonadosomatic index (GSI) for females of Loricariichthys spixii, in different maturation stages and parameters of the linear regression of testis weight on body weight.

\begin{tabular}{ccccccc}
\hline Stage & $\begin{array}{c}\text { GSI } \\
\text { average }\end{array}$ & $\begin{array}{c}\text { Standard } \\
\text { deviation }\end{array}$ & Confidence Interval & $\mathbf{a}$ & $\mathbf{b}$ & $\mathbf{n}$ \\
\hline 1 & 1.29 & 0.196 & $0.175-0.00053$ & -0.9851 & 0.02096 & 5 \\
$2 \mathrm{a}$ & 4.18 & 0.84 & $0.095-0.0017$ & 1.6706 & 0.03375 & 122 \\
$2 \mathrm{~b}$ & 6.33 & 0.235 & $0.139-0.002$ & 3.4762 & 0.0375 & 422 \\
$4 \mathrm{a}$ & 4.93 & 0.108 & $0.211-0.011$ & 3.8050 & 0.0331 & 332 \\
$4 \mathrm{~b}$ & 3.97 & 0.122 & $0.035-0.0039$ & 7.0786 & -0.0004 & 64 \\
\hline
\end{tabular}

$\mathrm{n}=$ number of individuals; $\mathrm{a}=$ regression constant; $\mathrm{b}=$ regression coefficient;

Table 5 - F-values and significance of ANOVA on gonadosomatic index (GSI) for males and females of Loricariichthys spixii for comparisons between bi-months and years, in Lajes reservoir, 1996-1997

\begin{tabular}{ccccl}
\hline & & & \multicolumn{2}{c}{ SNK - Test } \\
\cline { 4 - 5 } GSI & $\boldsymbol{F}$ & $\boldsymbol{p}$ & Year & \multicolumn{1}{c}{ Bimonth } \\
\hline Males & 2.82 & 0.0040 & $1996>1997$ & Sep-Oct 1996 > Mar-Jun 1996 and Nov 1996-Jun1997 \\
Females & 4.28 & 0.0001 & $1996>1997$ & Sep-Dec 1996; Mar-Apr 1997; Sep-Oct 1997 > Jul-Aug 1996 and 1997 \\
\hline
\end{tabular}


Table 6 - F-values and significance of ANOVA on environmental variables for comparisons between bi-months and years, in Lajes reservoir, 1996-1997** $\mathrm{P}<0.01$

\begin{tabular}{lllccc}
\hline \multicolumn{1}{c}{ Variables } & Year & Month & Year $\mathbf{x}$ & & SNK - Test \\
\cline { 5 - 6 } & & & Bimonth & Year & Month \\
\hline Temperature & $14.7^{* *}$ & $144.8^{* *}$ & $7.7^{* *}$ & - & $\mathrm{j} / \mathrm{f}>\mathrm{m} / \mathrm{a} ; \mathrm{n} / \mathrm{d}>\mathrm{m} / \mathrm{j}>\mathrm{s} / \mathrm{o}>\mathrm{j} / \mathrm{a}$ \\
Transparency & $252.0^{* *}$ & $55.4^{* *}$ & $17.2^{* *}$ & $1996>1997$ & $\mathrm{j} / \mathrm{a}>\mathrm{m} / \mathrm{a} ; \mathrm{m} / \mathrm{j} ; \mathrm{s} / \mathrm{o}>\mathrm{j} / \mathrm{f} ; \mathrm{n} / \mathrm{d}$ \\
$\mathrm{pH}$ & $94.4^{* *}$ & $19.7^{* *}$ & $13.2^{* *}$ & $1996>1997$ & $\mathrm{~m} / \mathrm{a} ; \mathrm{n} / \mathrm{d}>\mathrm{j} / \mathrm{f} ; \mathrm{s} / \mathrm{o}>\mathrm{m} / \mathrm{j} ; \mathrm{j} / \mathrm{a}$ \\
Water level & $92.5^{* *}$ & $63.7^{* *}$ & $10.8^{* *}$ & $1996>1997$ & $\mathrm{~m} / \mathrm{j} ; \mathrm{m} / \mathrm{a}>\mathrm{j} / \mathrm{f} ; \mathrm{j} / \mathrm{a}>\mathrm{s} / \mathrm{o} ; \mathrm{n} / \mathrm{d}$ \\
Rainfall & 0.5 & $26.9^{* *}$ & 3.0 & - & $\mathrm{j} / \mathrm{f} ; \mathrm{m} / \mathrm{a} ; \mathrm{n} / \mathrm{d}>\mathrm{m} / \mathrm{j}>\mathrm{j} / \mathrm{a} ; \mathrm{s} / \mathrm{o}$ \\
\hline
\end{tabular}

\section{DISCUSSION}

The population of L. spixii in the Lajes reservoir was comprised mainly by the females, which also reached relatively larger size than the males, and this pattern was consistent over the two studied years. Araújo et al. (1998) also found significant higher number of the females than the males. Sex rate is one of the most important parameters of population's structure. Nikolsky (1969) reported that sex rate varied according to age, depending on the species, reflecting the interaction with the environment, and suggested that areas with plenty of food presented higher proportions of females. Among the members of Loricariidae, the number of males was higher than the number of the females (Nomura and Mueller, 1980; Bruschi-Jr. et al., 1997), but there were some exceptions (Barbieri and Santos, 1987). Non-significant differences in sex rate for Loricariidae were found by Antoniutti et al., (1985) and Mazzoni and Caramaschi (1995). Several factors can influence sex rate: growth rates influence Plecostomus albopunctatus (Antoniutti et al., 1985); mortality rates influence $H$. affinis and Hypostomus luetkeni (Mazzoni and Caramaschi, 1997); differences on behavior between males and females or selective capture influence Pseudocurimata gilberti (Honda, 1979 apud Antoniutti et al., 1985); and partial segregation by sex influences Oligosarcus jenynsii (Hartz et al., 1997). Secondary sexual dimorphism allows easy distinction of males from females at all sizes in L. spixii in Lajes reservoir, although nothing has been cited for this aspect before. The most elongated labial papilla in the males, located in the antero-ventral area of the head, in opposite to a relatively shorter structure in females, was associated with the broodcare practiced by the former. According to Py-Daniel (1981), species of the gender Furcodontichthys share with Loricariichthys the same characteristic, with the males broodcaring and presenting elongated labial papilla. This sexual dimorphism was first observed for L. spixii by Steindachner (1881) and confirmed for Loricariichthys acuta by Eigenmann and Eigenmann (1890) apud Regan (1904) and Menezes (1949). Taylor (1983) observed that males of Loricariichthys simillia, Loricariichthys labialis, Loricariichthys platymetopon and Loricariichthys anus presented a great labial papilla development during the reproductive period, covering the whole ventral surface of the head, behind the mouth, where agglutinated eggs were attached. According to Bazzoli and Rizzo (1990), follicle cells from the vitellogenic oocytes of neotropical freshwater teleosteans played an important role in the vitelogenesis and in the oocyte final maturation phase. All the Loricariidae species presented in the composition of the follicles cells neutral glycoproteins and glyconjugate carboxylates acids. The variations of the glycoproteins of these cells could be related with the adhesiveness of the eggs of some species. According to macro and microscopic observations, the reproductive cycle was classified in five phases of gonadal development gonadal. This classification followed Bazzoli and Godinho (1991) as described for Acestrorhynchus lacustris. This methodology has been used thoroughly for other freshwater fish species such as Serrasalmus brandtii (Teles and Godinho, 1997), Shizodon knerii (Soares et al., 1996) Leporinus amblyhyrnchus and Leporinus striatulus (Ricardo et al., 1991), Astyanax bimaculatus (CangussuMariani et al., 1991). According to this classification, the stage is considered mature only when it reaches the climax of the gonadal maturation, that is, the exact moment of the ovulation or spermation. As this event is of short duration (Selman and Wallace, 1986), it is hardly observed. The distinction between the immature and resting stages, which are histologically differentiated due to the presence of ovuliger lamella in the later stage, being absent in immature 
females, is other phase that need careful observation to be determined. Testis in resting stage presents numerous spermatozoa and scarce interstitial strome, unlike immature stage, where there is abundant interstitial strome and spermatozoa randomly distributed, as reported by Soares et al. (1996). Although advanced maturation (2b) and partially empty (4a) stages appear rather similar in terms of number of spermatozoa/number of cells probably due to long reproductive season. Araújo et al. (1998) classified maturation stages based on macroscopic description of $L$. spixii following Vazzoler (1996). Stages ripe/spent corresponds to partially spawned in Araújo et al's classification.

Gonad morphology presented remarkable differences between the sexes, with different asymmetry types. Testis for L. spixii presented morphological characteristics differing from most of those described for other teleosteans (Vazzoler, 1982; 1996). It was flat and presented traverse folds, and the extremities with different formats that varied according to the reproductive cycle. Non-filliform or tubular testis were not common, as the case of $R$. aspera, which presented flat testis and folders in the outer margins, which became accentuated with the maturation, besides transversal folds in the mature fishes which gave lobuled aspect (Agostinho et al., 1986; 1990). Testis in P. striatulus (Araújo et al. 2000) presented folds during the whole reproductive cycle, varying in turgidity, coloration and size. Barbieri and Barbieri (1984) reported that testes of Gymnotus carapo were oval, sometimes taking a pyramidal form. The flat form was also reported for L. anus (Bruschi-Jr. et al., 1997). Barbieri and Barbieri (op cit) reported that testis coloration did not change much as compared with ovary, and that both the testes showed the same size, although in some cases this might not occur.

The L. spixii presented a morphological asymmetric pattern for the ovaries, but only in partially spawning / totally spawning stages due to probable elimination of eggs when the fish was caught, since that part of the oocytes were usually eliminated by the females. In other stages, such oocytes were not eliminated since they were not enough developed and the gonads did not present such asymmetry. This could be a mechanism to increase species survival. The pellucida zone was considered thin. Differently from the mammals, the pellucida zone in fish was complex, constituted by layers and presented radiate strays at light microscopy, being also called for this reason, radiate zone (Rizzo and Bazzoli, 1991).

The yolk is a nutritional reserve of accumulated material in the oocytes during its development and differs among species, especially in the proportion and amount of proteins, lipids and carbohydrates. In the teleosteans, there was large ranges in the chemical nature of the cortical vesicles and globules of yolk. Yolk globules in L. spixii were spherical, and in high amount. Yolk globules were formed in the cells of oocytarian lineage $\mathrm{O} 4$, the largest oocytes in the cell.

The long reproductive period seemed to be a rule for the gender Loricariichthys as stated by Vazzoler (1996), who reported Loricariichthys platymetopon and Loricariichthys sp as parcel spawning, with a wide reproductive period from October to March, coinciding with rainfall period. The Loricaria spp were also classified as iteroparous spawning but with a more restricted reproductive period, between November and January. The wide reproductive period was shown in this work for L. spixii, with resting in July/August for the females. Seasonal variations in the males GSI were less evident, with a trend of higher values in September-October 1996 and January-February 1997, coinciding with peaks in rainfall and temperatures, conditions usually favorable for neotropical fish reproduction. Water levels did not match rainfall season due to the highest hydroelectric power demands during the summer. This disturbance could contribute to the wide reproductive period, a mechanism to increase eggs and juvenile survival by the species. Duarte and Araújo (2001) found a close relationship between the water level and $L$. spixii abundance and attributed this pattern to the increased feeding resources availability and shelter during the high water level season. Overall L. spixii probably found in Lajes reservoir favorable environmental conditions to its development, as indicated by its remarkable high abundance in this relatively closed environment.

\section{CONCLUSIONS}

1. The structure of $L$. spixii population in the Lajes reservoir showed an asymmetric sexual pattern, with females being more abundant than males, and also reaching larger sizes. 
2. Four gonadal development phases were detected for both the sexes: males -spermatogonia (primary and secondary), spermatocytes (primary and secondary), spermatids and spermatozoa; females - primary oocytes (O1), previtellogenic oocytes $(\mathrm{O} 2)$, cortical vesicle oocytes $(\mathrm{O} 3)$ yolk globules or vitellogenic $(\mathrm{O} 4)$

3. Five gonadal stages were described for the males/females: resting (1); initial maturation (2a); advanced maturation ( $2 b$ ); partially spent/spawned (4a); totally spent/spawned (4b).

4. This species was iteroparous spawning with resting/recover occurring in July/August for the females, coinciding with lower temperature and rainfall and decreasing water level. The wide spawning period seemed to be the part of the strategy developed by this species to withstand environmental pressure (biotic and abiotic).

\section{ACKNOWLEDGMENTS}

We thank all the technicians and undergraduate students at Fish Ecology Laboratory, University Federal Rural of Rio de Janeiro, for helping in field and laboratory work. We are indebted to Benjamin Teixeira de Carvalho Pinto for many suggestions that helped to improve the first drafts of the manuscript. We also thank Mônica Cândida Pereira Ricardo, Laboratory of Ictio-hystology from University Federal of Minas Gerais for helping in histological techniques. We thank specially Drs. Sebastião Paulino and Ricardo Bichara. This work is a portion of the first author Ms. Dissertation of Environmental Sciences Course from University Federal Rural of Rio de Janeiro. The project was partially financed by Brazilian Agency for Research Development $\mathrm{CNPq}$ and Brazilian. Ministry of Education Coordination for Personal Training - CAPES. LIGTH Services of Electricity S.A., concessionaire of the Lajes Reservoir, supplied infrastructure, essential to the project development and additional financial support.

\section{RESUMO}

A morfologia das gônadas e a época de desova de Loricariichthys spixii, no reservatório de Lajes foi descrita baseada em 175 machos e 613 fêmeas, coletados de Janeiro-1996 a Dezembro-1997.
Células de linhagem espermatogênica foram divididas em 4 fases: espermatogônias (primárias e secundárias), espermatócitos (primários e secundários), espermátides e espermatozóides, enquanto as células de linhagem ovocitária também foram divididas em 4 fases, baseadas em características do núcleo, ooplasma e folículos dos ovócitos: ovócitos primários (O1), ovócitos previtelogênicos (O2), ovócitos de vesícula cortical (O3) e glóbulos de vitelo ou vitelogênicos (O4). Cinco estádios gonadais foram descritos para machos/fêmeas de acordo com a distribuição das células de linhagem ovocitária / espermatogênicas: repouso (1); maturação inicial (2a); maturação avançada (2b); parcialmente esvaziado/desovado (4a); totalmente esvaziado/desovado (4b). Desova é parcelada, ocorrendo através do ano. O repouso/recuperação ocorreu em Julho/Agosto para fêmeas coincidindo com menores temperaturas e pluviosidades, e diminuições do níveis da água. $\mathrm{O}$ amplo período reprodutivo é parte da estratégia desenvolvida por esta espécie para suportar as pressões ambientais (bióticas e abióticas) e obter sucesso neste reservatório oligotrófico e pobremente estruturado.

\section{REFERENCES}

Agostinho, A. A.; Barbieri, M. C.; Barbieri, G. and Agostinho, C.S. (1986), Biologia reprodutiva de Rhinelepis aspera (Agassiz, 1829) (Teleostei, Loricariidae ) no Rio Paranapanema . II. Estrutura dos ovários e estádios de maturação. Revista Brasileira de Biologia, 47, 319-328

.Agostinho, A. A; Barbieri, G.; Verani, J.R. and Hahn, N. S. (1990), Variação do fator de condição e do índice hepatossomático e suas relações com o ciclo reprodutivo em Rhinelepis aspera (Agassiz, 1829) (Ostheichthyes, Loricariidae) no rio Paranapanema. Ciência e Cultura, 42, 711-714.

Antoniutti, D.M.; Godinho, H. M. and Ranzani-Paiva, M.J.T. (1985), Estrutura da população, reprodução e crescimento do cascudo Plecostomus albopunctatus, Regan, 1908. (Ostheichthyes, Loricariidae) do Rio Jaguarí, São Paulo. Brasil. Boletim do Instituto de Pesca, 12, 121-131.

Araújo, F.G.; Fichberg, I. and Duarte, S. (1998), Ciclo reprodutivo de Loricariichthys spixii (Steindachner, 1882) (Pisces Loricariidae) na represa de Ribeirão das Lajes, RJ. Acta Bioogica Leopoldensia, 20, 309318. 
Araújo, F. G; Duarte, S; Goldberg, R.S. and Fichberg, I. (2000), Ciclo reprodutivo de Parauchenipterus striatulus (Pisces Auchenipteridae) na represa de Ribeirão das Lajes, RJ. Arquivos Brasileiros de Medicina Veterinária e Zootecnia, 52, 276-284.

Barbieri, G. and Barbieri, M. C. (1984), Note on nutritional dynamics of Gymnotus garapo from de Lobo Reservoir, São Paulo State, Brazil. Journal of Fish Biology, 24, 351-355.

Barbieri, G. and Santos, G. (1987), Crescimento e tamanho de primeira maturação gonadal de Hypostomus aff. plecostomus (Linnaeus, 1758) (Osteichthyes, Loricariidae), na represa de Monjolinho (São Carlos, SP). Ciência e Cultura, 39, 659-663.

Barroso, L. V. (1989), Diagnóstico ambiental para a pesca de águas interiores no estado do Rio de Janeiro. Rio de Janeiro, IBAMA-Doc. ACUMEP 4, 177p.

Bazzoli, N. and Rizzo, E. (1990), A comparative cytological and cytochemical study of the oogenesis in tem brasilian teleost fish species. European Archives of Biology, 101: 399-410.

Bazzoli, N. (1992), Ovogênese em peixes teleósteos neotropicais de água doce. Tese de Doutorado em Morfologia, Universidade Federal de Minas Gerais. Belo Horizonte, MG. 182 pp.

Bazzoli, N. and Godinho, H.P. (1991), Reproductive biology of the Acestrorhynchus lacustriis (Reinhand, 1874) (Pisces, Characidae) from Três Marias Reservoir. Brazilian Zooloogical Anz, 226, 285 - 299.

Bruschi-Jr, W.; Peret, A. C.; Verani, J.R. and Fialho, C.B. (1997), Reprodução de Loricariichthys anus (Valenciennes, 1840) da lagoa Emboaba, Osório, RS, Brasil. Revista Brasileira de Biologia, 57, 677-685.

Cangussu-Mariani, S. D. (1991), Morfologia e desenvolvimento do núcleo vitelínico de lambari Astyanax bimaculatus (Linnaeus, 1758) (Osteichtyes, Characidae). Revista Brasileira de Zoologia, 7, 207213.

Conover, D. O. (1992), Seasonality and the scheduling of life history at different latitudes. Journal of Fish Biology, 41, 161-178.

Duarte, S. and F. G. Araújo. (2000), Fecundity de Loricariichthys spixii no reservatório de Lajes, RJ Revista Brasileira de Zoologia, 8(8): 25-31.

Duarte, S. and F. G Araújo. (2001), Abundância relativa e distribuição de Loricariichthys spixii no reservatório de Lajes, RJ - Revista Brasileira de Zoologia, 18(2), 465-477.

Eigenmann, C.H. and Eigenmann, R.S. (1890), A revision of the South American Nemathgnathi or catfishes. Occasional Papers of the California Academy of Sciences, 1, 1-508.

Hartz, S.M.; Vilella, F.S. and Barbieri, G. (1997), Reproduction dynamics of Oligosarcus jenynsii (Characiformes, Characidae) in lake Caconde, Rio Grande do Sul, Brazil. Revista Brasileira de Biologia, 57, 295-303.
Mazzoni, R. and Caramaschi, E. P. (1995), Size, structure, sex ratio and onset of sexual maturity of two species of Hypostomus. Journal of Fish Biology, 47, 841-849.

Mazzoni, R. and Caramaschi, E. P. (1997), Spawing season, ovarian development and fecundity of Hypostomus affinis (Osteichthyes, Loricariidae). Revista Brasileira de Biologia, 57, 455-462.

Menezes, R. S. (1949), Incubação labial de ovos pelo macho de Loricaria typus Bleeker, da lagoa do Peixe, Piauí, Brasil (Actynopterygii, Loricariidae, Loricariinae). Revista Brasileira de Biologia, 9, 381387.

Nikolsky, G. V. (1969), Theory of fish population dynamics. Oliver and Bloyd, Edimburgh, $323 \mathrm{pp}$.

Nomura, H. and Mueller, I. M. (1980), Biologia do cascudo, Plecostomus hermanni Ihering, 1905 do rio Mogi guaçu. São Paulo (Osteichthyes, Loricariidae). Revista Brasileira de Biologia, 40, 267-275.

Py-Daniel, L. H. R. (1981), Furcodontichthys novaesi n. gen., n. sp. (Osteichthys, Siluriformes, Loricariidae) na bacia Amazônica, Brasil. Boletim do Museu Paraense Emílio Goeldi, 105: 1-17.

Regan, C. T. (1904), A monograph of the fishes of the family Loricariidae. Transacation of the Zoological Society of London, 17, 191-350.

Ricardo, M. C. P.; Santos, G. S.; Rizzo, E. and Bazzoli, N. (1991), Aspectos reprodutivos de Leporinus amblyrhynchus (Pisces; Anastomidae) no reservatório de Furnas, MG. Bios, 5, 29-35.

Rizzo, E. and Bazzoli, N. (1991), The zona pellucida of the brazilian white Piranha, Serrasalmus brandtii Reinhardt 1874 (Pisces, Characide): A cytological and cytological study-Funcional and Developmental Morphology, 1(4), 21-24.

Santos JE; Bazzoli, N; Rizo, G. B. (2001). Morphofunctional organization of the male reproductive system of the catfish Iheringichthys labrosus (Lütken, 1874) (Siluriformes: Pimelodidae). Tissue Cell: 33 (5): 533-540

Selman, K.; Wallace, R. A. (1986), Review celular aspects of oocyte growth in teleosts. Zoological Scientist, 6, 211-231.

Soares, M.G.; Dabes, A. C.; Sato, Y. and Bazzoli, N. (1995), Tamanho da primeira maturação sexual do Schizodon knerii e do Leporinus piau (Teleostei, Anostomidae) na represa de Três Marias, MG. Arquivo Brasileiro de Medicina Veterinária $e$ Zootecnia, 48, 47-54.

Steindachner, F. (1881), Beiträge zur kenntniss der flussfische Südamerika's III (Beschreibungen von 51 Fisch-Arten). Denamark Akademy Wiss Wien, 44, 118.

Taylor, J. N. (1983), Field observation on the reproductive ecology of three species of catfishes (Loricariidae: Loricariinae) in Paraguai. Copeia, 1983, 257-259. 
Teles, M. E. O and Godinho, H. P. (1997), Ciclo reprodutivo da pirambeba Serrassalmus brandtii (Teleostei , Characidae) na represa de Três Marias, Rio São Francisco. Revista Brasileira de Biologia, 2, 177-184.

Vazzoler, A. E. A. M. (1982), Manual de métodos para estudos biológicos de populações de peixes: reprodução e crescimento. CNPq. Prog. Nac. Zoologia. Brasília, 108 pp

Vazzoler, A. E. A. M. (1996), Biologia da reprodução de peixes teleósteos: teoria e prática., Eduem/ SBI/CNPq/Nupelia, Maringá, 169 pp.

Zar, J. H., (1984), Biostatistical Analysis. Prentice Hall, Englewood Cliffs, California, 718 pp. 